\title{
Evaluation of an oral preventive protocol in children with acute lymphoblastic leukemia
}

\section{Avaliação de um protocolo preventivo oral em crianças com leucemia linfoblástica aguda}

\author{
Edja Maria Melo de Brito Costa* \\ Maria Zélia Fernandes** \\ Lêda Bezerra Quinderé*** \\ Lélia Batista de Souza**** \\ Leão Pereira Pinto****
}

\begin{abstract}
This study was designed to assess the effectiveness of a preventive oral protocol in children receiving antineoplastic treatment for acute lymphoblastic leukemia (ALL) before initiating a larger intervention study. During a seven month period, fourteen children from two to ten years old with a diagnosis of ALL were evaluated. Patients with ALL who received a $0.12 \%$ chlorhexidine mouth rinse (seven children) were compared to a control group of patients who were not given the same preventive treatment (seven children) as to the occurrence of oral mucosal complications. Children in both groups received daily oral hygiene care, and were examined daily by the pediatric dentistry team until discharge. A significant decrease in the incidence of oral mucositis and ulceration was observed in the children who received a $0.12 \%$ chlorhexidine mouth rinse ( $p<0.05$ by Fisher's exact test). The findings obtained in the present trial are encouraging, and suggest that the systematic application of a preventive protocol reduces the incidence of oral complications in children with ALL receiving chemotherapy.

DESCRIPTORS: Leukemia; Drug therapy; Mouth mucosa; Chlorhexidine.
\end{abstract}

RESUMO: O objetivo do presente estudo foi verificar a eficácia de um protocolo oral preventivo em crianças com leucemia linfoblástica aguda (LLA), submetidas ao tratamento antineoplásico, antes de iniciar um estudo mais abrangente. Durante um período de sete meses, foram avaliadas, consecutivamente, quatorze crianças com LLA, de dois a dez anos de idade. As crianças com LLA que fizeram bochechos com a solução de clorexidina 0,12\% (sete crianças) foram comparadas com aquelas do grupo controle (sete crianças) no que diz respeito ao surgimento de lesões orais. Todas as crianças do estudo receberam diariamente orientação de higiene oral e foram igualmente examinadas pelo odontopediatra. Observou-se uma diminuição significativa na incidência de mucosite e ulceração oral nas crianças que fizeram bochecho profilático com clorexidina $0,12 \%$ ( $<<0,05$, teste exato de Fisher). Os achados obtidos no presente estudo são satisfatórios, e sugerem que uma aplicação sistemática de um protocolo preventivo reduza a incidência de complicações orais em crianças com LLA submetidas à quimioterapia.

DESCRITORES: Leucemia; Quimioterapia; Mucosa oral; Clorexidina.

\section{INTRODUCTION}

Immunosuppressive chemotherapy and bone marrow transplantation have been increasingly used to treat and, in some cases, cure numerous malignant conditions ${ }^{14}$. The systemic sequelae as a result of these immunosuppressive techniques induce many oral and dental complications. The direct and indirect stomatotoxic effects are associated with the development of ulcerative, hemorrhagic, or infectious complications ${ }^{12,14}$. As a consequence, all these problems can potentially cause increasing mortality and morbidity ${ }^{14}$.
Intensive chemoradiotherapy damages the mucosal barrier of the mouth and throat and it is often associated with severe oral inflammation and infection, including herpes simplex, candidiasis, mucositis, and gingivitis ${ }^{1,2,7,9,13}$. In addition, these oral complications interfere with patients' comfort, nutrition and may lead to a systemic infection originated in the mouth ${ }^{19}$.

The increased risk for systemic fungal infection and the potential fatal consequences of disseminated candidiasis in patients receiving bone marrow transplants or cytotoxic antineoplastic

*PhD, Pediatric Dentistry, School of Dentistry, Potiguar University.

**MD, Pediatric Medicine, Department of Hematology, School of Medicine; ***PhD, Oral Pathology, Department of Pediatric Dentistry; ${ }^{* * *} \mathrm{PhD}$, Oral Pathology, Department of Oral Pathology - Federal University of Rio Grande do Norte. 
Costa EMM de B, Fernandes MZ, Quinderé LB, Souza LB de, Pinto LP. Evaluation of an oral preventive protocol in children with acute lymphoblastic leukemia. Pesqui Odontol Bras 2003;17(2):147-50.

therapy has originated several studies about prophylaxis of candidiasis, mucositis, ulceration, hemorrhage or infection ${ }^{3,5,7-17,19}$.

The oral health status of hospitalized children suffering from leukemia or other cancers is generally poor ${ }^{6}$. They should be considered as high risk patients for oral complications, a situation which requires both suitable dentist and medical te$\mathrm{ams}^{4,20}$. However, in some cases, patients undergoing cytotoxic chemotherapy and radiation therapy often experience severe oral complications during and after treatment despite the supervised oral hygiene and conventional antimicrobial regimens ${ }^{9}$.

A variety of chemical substances has been used for the prevention and treatment of chemotherapy-induced oral complications, such as chlorhexidine $\mathrm{e}^{5,7,9,12-14,16}$, vitamin $\mathrm{E}^{18}$, itraconazole ${ }^{10}$, fluconazole ${ }^{8}$, oral sucralfate suspension ${ }^{15}$, and low energy helium-neon laser ${ }^{3}$.

The chlorhexidine mouthwash has been widely used for the aforementioned purpose. The main reason for the use of this drug is the fact that it represents an antimicrobial compound and an effective topical prophylactic agent against oral mucositis and candidiasis ${ }^{9}$. The relevant literature presents conflicting results with respect to the prophylactic use of chlorhexidine in patients with leukemia or those who have a bone marrow transplant $^{5,7,912-14,16}$.

The aim of this study was to assess the effectiveness of a preventive oral protocol using chlorhexidine mouthrinses in preventing chemotherapy-induced oral mucosal complications in children receiving intensive chemotherapy for acute lymphoblastic leukemia (ALL) before initiating a wider intervention study.

\section{MATERIALS AND METHODS}

Fourteen children, two to ten years of age (mean $=7$ years $)$, receiving intensive chemotherapy for treatment of acute lymphoblastic leukemia were evaluated. These children were admitted to the Varela Santiago Hospital Service, Natal, Rio Grande do Norte, Brazil. They received an identical intensive chemotherapy regimen for a six-week period. The intensive therapy consisted of 6-mercaptopurine (an oral dose of $50 \mathrm{mg} / \mathrm{m}^{2} /$ day during six weeks), methotrexate (an intravenous dose of $2 \mathrm{mg} / \mathrm{m}^{2}$ in continuous infusion for 24 hours on days $1,15,30$ and 45), leucovorin (an oral dose of $15 \mathrm{mg} / \mathrm{m}^{2}$ four times per day, on days $2,3,16,17$, $31,32,46$ and 47) and MADIT intrathecal (a combination of methotrexate $12 \mathrm{mg}+$ cytosine arabi- noside $70 \mathrm{mg}$ + dexametasone $2 \mathrm{mg} / \mathrm{m}^{2}$ ) on days 1 , 15, 30 and 45. The protocol and informed consent were reviewed and approved by the ethical review board, Federal University of Rio Grande do Norte, Brazil. The informed consent was obtained from the parents or guardians of all children.

No children had any clinical signs of oral or esophageal candidiasis nor any other oral complications on the mucosa before initiating the preventive oral protocol and the intensive chemotherapy. The chemotherapy regimen employed for the intensive period was identical in all patients. Younger children were included in the control group.

The preventive oral protocol was performed during the intensive period of the chemotherapy. It started at least one day before initiating the intensive chemotherapy and ended ten days after the end of this period, with an average length of eight weeks. In the experimental group, seven patients received a daily preventive protocol consisting of an oral hygiene care, including twice a day (in the morning and in the evening) teeth brushing, supervised by guardians, parents and/or dentist, and mouthrinses with a non-alcoholic solution of $0.12 \%$ chlorhexidine (Ao Pharmacêutico, Natal, RN, Brazil). The seven children of the control group received a daily oral hygiene care, including twice a day (in the morning and in the evening) supervised brushing and mouthrinses with a placebo mouthwash. Both groups were then similarly evaluated daily by the same pediatric dentist for oral mucosal complications during the intravenous and intrathecal drug administration of the intensive therapy.

\section{Statistical analysis}

The data were analyzed statistically by means of Fisher's exact test. A p value $<0.05$ was considered significant.

\section{RESULTS}

During the experimental period all the children maintained good oral hygiene. A significant decrease in the incidence of mucositis and ulceration in the children who received the preventive oral protocol using $0.12 \%$ chlorhexidine mouthrinses was observed ( $\mathrm{p}<0.05$; Fisher's exact test). One children $(14.3 \%)$ of the experimental group and five (71.4\%) of the control group developed oral mucositis and ulceration (Figures 1 and 2). No other oral mucosa complication was observed. Mucositis developed between two and four days after the initial administration of the intravenous dose of metho- 


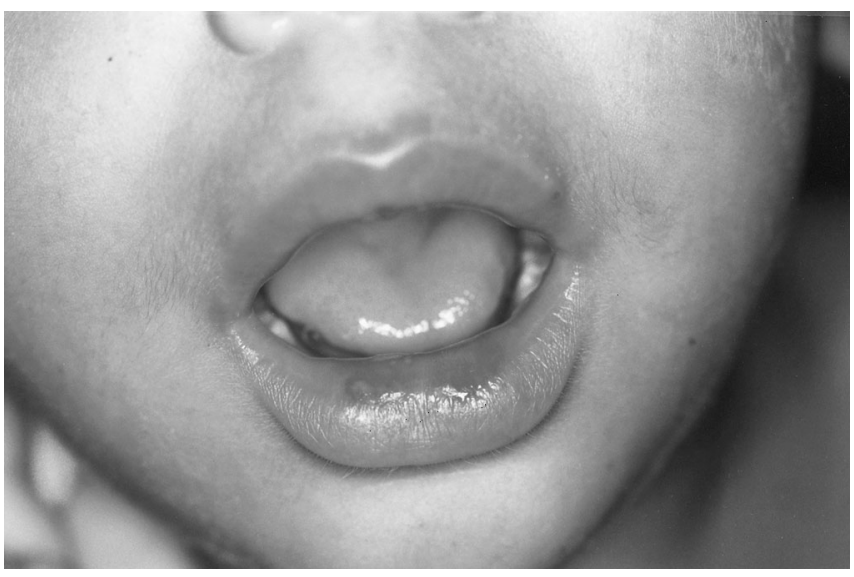

FIGURE 1 - Mucositis and ulceration in the labial mucosa. Five days after initial administration of intravenous dose of methotrexate.

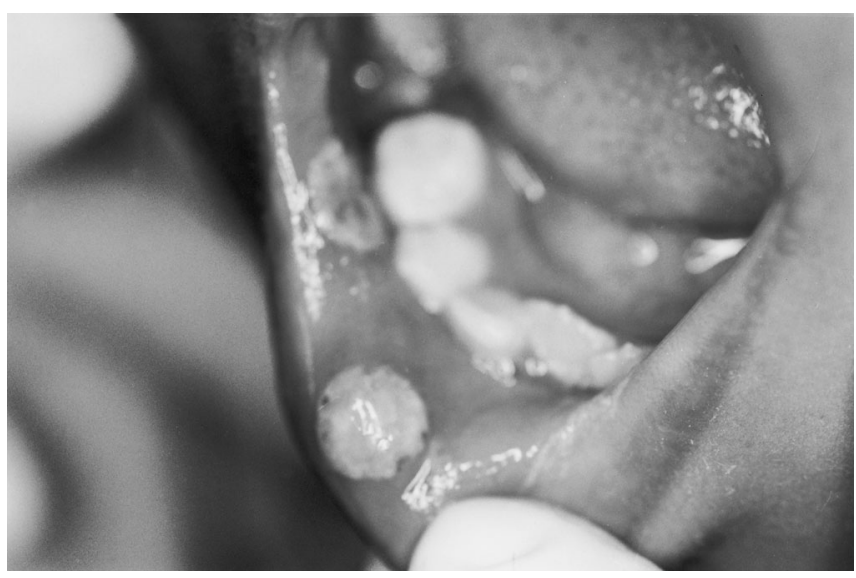

FIGURE 2 - Ulceration in the labial mucosa. Six days after initial administration of intravenous dose of methotrexate.

trexate, and this was more frequent on the labial and buccal mucosa. The average durations of mucositis and ulceration was ten and sixteen days, respectively. The severity of the oral lesions and their duration in the child who received chlorhexidine mouthrinses were lesser compared to the control group. No toxicity was observed in this study. Only the child who developed mucositis in the experimental group reported a burning sensation in the mouth associated with the chlorhexidine mouthwash.

\section{DISCUSSION}

The results of this study confirm previous studies regarding the usefulness of a preventive oral protocol using a chlorhexidine mouthrinse for the prevention of chemotherapy-induced oral complications, including oral mucositis and Candida infections, in children with leukemia receiving intensive chemotherapy ${ }^{9,12-14,16}$.

In the present study, children who were submitted to a preventive oral protocol including a chlorhexidine mouthwash exhibited fewer mucositis lesions. Only one (14.3\%) of the seven children who used chlorhexidine experienced oral mucositis. These findings indicate that oral soft tissue disease associated with chemotherapy can be dramatically reduced if a prophylactic oral protocol is applied in association with the chemotherapy.

Consistent with the findings of Ferretti et al. ${ }^{9}$ (1987) the preventive oral protocol using chlorhexidine mouthrinses can reduce both the incidence and the severity of oral lesions in children suffering from leukemia receiving chemotherapy. In addition to its value in protecting severely immunocompromised patients from oral mucosa complications, chlorhexidine also offers a therapeutic benefit in the resolution of existing therapyinduced oral soft tissue disease ${ }^{9}$.

In contrast, other studies ${ }^{5,7}$ do not support the use of chlorhexidine mouthrinses for the prevention of mucositis in patients with bone marrow transplantation or with leukemia receiving chemotherapy who are able to maintain good oral hygiene by mechanical means during their illness.

\section{CONCLUSIONS}

The results obtained in this limited number of patients are promising. We support that the preventive oral protocol applied in the present study may be used as an oral complications prophylaxis for children with leukemia who are receiving intensive chemotherapy. Besides, it may be justified to obtain and maintain the best possible oral health in seriously ill patients, because an improvement of the oral conditions may diminish their suffering and prevent the spread of serious infections from the oral cavity. These results have been used to improve the ongoing larger intervention study.

\section{ACKNOWLEDGEMENT}

Financial support for this study was provided by the Conselho Nacional de Desenvolvimento Científico e Tecnológico (CNPq). 
Costa EMM de B, Fernandes MZ, Quinderé LB, Souza LB de, Pinto LP. Evaluation of an oral preventive protocol in children with acute lymphoblastic leukemia. Pesqui Odontol Bras 2003;17(2):147-50.

\section{REFERENCES}

1. Baliga AM, Brave VR, Vyas HA. Oral mucosal lesions in patients with acute leukemias and related disorders due to cytotoxic therapy. J Indian Soc Pedod Prev Dent 1995; 13:25-9.

2. Carrega G, Castagnola E, Canessa A, Argenta P, Haupt R, Dini $\mathrm{G}$, et al. Herpes simplex virus and oral mucositis in children with cancer. Support Care Cancer 1994;2:266-9.

3. Cowen D, Tardieu C, Schuber M, Peterson D, Resbeut M, Faucher C, et al. Low energy helium-neon laser in the prevention of oral mucositis in patients undergoing bone marrow transplant: results of a double blind randomized trial. Int J Radiat Oncol Biol Phys 1997;38:697-703.

4. Dens F, Boute P, Otten J, Vinckier F, Declerck D. Dental caries, gingival health, and oral hygiene of long term survivors of paediatric malignant diseases. Arch Dis Child 1995; 72:129-32.

5. Dodd MJ, Larson PJ, Dibble SL, Miaskowski C, Greenspan $\mathrm{D}$, MacPhail L, et al. Randomized clinical trial of chlorhexidine versus placebo for prevention of oral mucositis in patients receiving chemotherapy. Oncol Nurs Forum 1996;23:921-7.

6. Donatsky O, Ahlgren P, Hansen PF. Oral health status and treatment needs in long-term medicine patients in a Copenhagen hospital department. Community Dent Oral Epidemiol 1980;8:103-9.

7. Epstein JB, Vickars L, Spinelli J, Reece D. Efficacy of chlorhexidine and nystatin rinses in prevention of oral complications in leukemia and bone marrow transplantation. Oral Surg Oral Med Oral Pathol 1992;73:682-9.

8. Epstein JB, Ransier A, Lunn R, Chin E, Jacobson JJ, Le N, et al. Prophylaxis of candidiasis in patients with leukemia and bone marrow transplants. Oral Surg Oral Med Oral Pathol Oral Radiol Endod 1996;81:291-6.

9. Ferretti GA, Ash RC, Brown AT, Largent BM, Kaplan A, Lillich TT. Chlorhexidine for prophylaxis against oral infections and associated complications in patients receiving bone marrow transplants. J Am Dent Assoc 1987; 114:461-7.

10. Foot AB, Veys PA, Gibson BE. Itraconazole oral solution as antifungal prophylaxis in children undergoing stem cell transplantation or intensive chemotherapy for haematological disorders. Bone Marrow Transplant 1999; 24:1089-93.

11. Foote RL, Loprinzi CL, Frank AR, O'Fallon JR, Gulavita S, Tewfik $\mathrm{HH}$, et al. Randomized trial of a chlorhexidine mouthwash for alleviation of radiation-induced mucositis. J Clin Oncol 1994;12:2630-3.

12. Levy-Polack MP, Sebelli P, Polack NL. Incidence of oral complications and application of a preventive protocol in children with acute leukemia. Spec Care Dentist 1998; 18:189-93.

13. McGaw WT, Belch A. Oral complications of acute leukemia: prophylactic impact of a chlorhexidine mouth rinse regimen. Oral Surg Oral Med Oral Pathol 1985;60:275-80.

14. Rutkauskas JS, Davis JW. Effects of chlorhexidine during immunosuppressive chemotherapy. A preliminary report. Oral Surg Oral Med Oral Pathol 1993;76:441-8.

15. Shenep JL, Kalwinsky DK, Hutson PR, Geirge SL, Dodge RK, Blankenship KR, et al. Efficacy of oral sucralfate suspension in prevention and treatment of chemotherapy-induced mucositis. J Pediatr 1988;113:758-63.

16. Solomon CS, Shaikh AB, Arendorf TM. An efficacious oral health care protocol for immunocompromised patients. Spec Care Dentist 1995;15:228-323.

17. Turhal NS, Erdal S, Karacay S. Efficacy of treatment to relieve mucositis-induced discomfort. Support Care Cancer 2000;8:55-8.

18. Wadleigh RG, Redman RS, Graham ML, Krasnow SH, Anderson A, Cohen MH. Vitamin E in the treatment of chemotherapy-induced mucositis. Am J Med 1992;92:481-4.

19. Weisdorf DJ, Bostrom B, Raether D, Mattingly M, Walker P, Pihlstrom B, et al. Oropharyngeal mucositis complicating bone marrow transplantation: prognostic factors and the effect of chlorhexidine mouth rinse. Bone Marrow Transplant 1989;4:89-95.

20. Willershausen B, Lenzner K, Hagedorn B, Ernst C. Oral health status of hospitalized children with cancer: a comparative study. Eur J Med Res 1998;14:480-4.

Recebido para publicação em 10/06/02

Enviado para reformulação em 14/01/03

Aceito para publicação em 09/04/03 